\title{
Thought (Episteme) System About Women in Trilogy On Rara Mendut Novel by Y.B. Mangunwijaya
}

\author{
Siti Maisaroh ${ }^{1,}$ Muhammad Saibani Wiyanto $^{2}$
}

\author{
${ }^{1}$ STKIP PGRI Jombang \\ ${ }^{2}$ STKIP PGRI Jombang \\ ${ }^{*}$ Corresponding author. Email: maysaroh65@gmail.com
}

\begin{abstract}
The study aimed to describe the system of thought (episteme) about women in the trilogy of the Rara Mendut novel by Y.B. Mangunwijaya. The method used the archaeological knowledge of Michel Foucault. The data source of this research is the novel trilogy of Rara Mendut by Y.B. Mangunwijaya, consisting of three novels namely: Rara Mendut (RM), Genduk Duku (GD), and Lusi Lindri (LL) published by P.T. Gramedia Pustaka Utama, published in 2009, with a total of 799 pages. Data collection techniques used the documentation method or library documentation. Data analysis was carried out using a descriptive method that was referenced/guided by the archaeological theory of knowledge and genealogy of Michel Foucault. The results proved that the system of thought (episteme) about women in the novel trilogy is in the form of: a system of thinking about women in the eyes of rulers who are treated like decorations, even as inanimate objects, soulless and their dignity is not touched by the thoughts of royal officials; the system of thinking about women which was always associated with power and authority for the Mataram aristocrats at that time; and the system of thinking about women and supernatural powers which are very closely related.
\end{abstract}

Keywords: Thought (Episteme), System, Trilogy, Rara Mendut Novel

\section{INTRODUCTION}

The topic of women/women throughout the history of human life is always interesting, both in the discussion by fellow women especially fellow men, old and young people. The patriarchal culture in its system of thought in fact places women/women as binary. On the one hand, women are recognized for their existence as individuals who also have natural advantages over men, for example (conceiving, giving birth, and breastfeeding). On the other hand, physical condition and social position are often considered weak, not as strong as men in terms of skills and even tend to be abused. The nature of women/women is also in line with the opinion of Shihab [1] which states that it is undeniable that ignoring women means ignoring half of the potential of society, harassing women means harassing all humans because no one except Adam and Eve was not born through a woman. female.

The views and treatment of women/women from the past until now towards women since the era of the Mataram kingdom, is there a correlation with the implementation, it seems that there are still parallels. The issue of how the system of thinking systems of thought towards women in the millennial era can now be observed from what is recorded in Y.B.'s Rara Mendut novel trilogy. Researchers who use the object of study of Y. B. Mangunwijaya's novel generally relate it to the theory of feminism, while in terms of the substance of knowledge and philosophical ideas, no one has discussed it. Mangunwijaya as the object of this research. Therefore, this study raises the topic of the system of thought (episteme) about women in Y.B.'s Rara Mendut novel trilogy. Mangunwijaya.

The word "archaeology" has a different meaning than the usual meaning, namely archeology. More concretely, it means that every era has a "system of thought" that directs the way science is practiced in that era. This system of thought by Foucault is called episteme and usually remains implicit which is not the same as the explicit scientific theory that existed at that time. Attempts to make explicit or "excavate" the episteme that determines a certain period by Foucault archeology or archaeological analysis [2].

Foucault digs deep to demonstrate the power play he sees at work in the many rule and exception systems, 
ideas about sexuality, attitudes toward madness, crime, and torture. His method of social archeology uses the term "episteme". Episteme is a system of thought and controlling concept that is the basis of every age. The episteme of the renaissance is different from that of modern times, the renaissance sees the commonalities everywhere in "the theater of life", while modern times use history as its episteme. In his later work, Foucault prefers to talk about discourse rather than episteme [3]. The term episteme is Foucault's term for the system of discourse and understanding that is the basis for different eras [3].

Episteme can be thought of as something similar to a point of view (world-view), a cursory history of all branches of knowledge, which attaches the same standards and assumptions, a general level of ratio, a certain structure of thought that cannot be avoided by humans at one time in each of these branches of knowledge. Episteme is the whole relationship that unites discursive practice, at one time, which gives rise to epistemological patterns, science and formal systems [4].

Episteme (discourse system) is a key term in Foucault's thought about history. Foucault critically sees how the sciences develop in history systematically (the whole system of thinking) in one period, then change completely in another period, sometimes rapidly (Leksono, 2002, pp. 22-31). There are three characteristics of Foucault's 'episteme': 1) episteme determines how to see and experience reality. How to experience reality determines how to see reality, 2) the episteme of prohibitions, denial, neglect, and rejection. Episteme controls and controls human knowledge through three kinds of exceptions: taboo, madness, and untruth, 3) episteme there is a relationship between language and reality. Language for Foucault is a tool used by episteme to organize and compose reality according to the character of the episteme itself [5].

According to Foucault, each era has certain assumptions, certain principles, certain conditions of possibility, certain ways of approaching. Or in other words, each era has a certain historical a priori. Foucault tries to explore the episteme that determines the various eras [2]. Episteme is the totality of relations that can be found at any given time, between the sciences when one analyzes the sciences at the level of their discursive regularity. Episteme opens a very wide area and can never be closed. He is a set of articulations, shifts, and simultaneouss that never stand still [4]. Episteme is a component of various rules that underlie and regulate the production of discourse at a certain time [4].

This study used the concept of episteme referring to Foucault's opinion, namely finding and describing a system of thought which is a set/component of various rules underlying the discourse in the novel.

\section{METHOD}

Archeology and genealogy can be interpreted broadly as 'qualitative' methods, Foucault always uses text as data or what he sometimes calls archives, Scheurich [6]. Archeology as a methodological approach is intended to explore real and specific historical conditions with various statements combined and arranged to form and define a particular field of knowledge/object which requires the existence of a certain set of concepts and determines the limits of a certain regime of truth (ie what is seen as truth). Foucault tries to identify the historical conditions and values that determine the formation of object-oriented ways of speaking, discursive practices and discourse formation [7].

The working method of archeology in this research is to see and explore knowledge related to the system of thought (episteme) which is reflected in the trilogy of novels Rara Mendut by Y.B. Mangunwijaya. The system of thought (episteme) in the novel trilogy can be revealed through painting events and painting characters. The description of the thought system (episteme) about women contained in the trilogy in the subsequent analysis is linked to values that have character dimensions through character paintings and events.

The data source of this research is the novel trilogy of Rara Mendut by Y.B. Mangunwijaya, consisting of three novels namely: Rara Mendut (RM), Genduk Duku (GD), and Lusi Lindri (LL) published by P.T. Gramedia Pustaka Utama, published in 2009, with a total of 799 pages.

Data collection techniques in this study used the documentation method, in the form of library documentation. The literature in question is in the form of texts in novels and sources from history that are related to the focus of research referring to the archaeological theory of knowledge and Michel Foucault's genealogy. Data analysis in this study was carried out using a descriptive method that was referenced/guided by the archaeological theory of knowledge and genealogy of Michel Foucault. The steps are since data collection, data analysis activities are simultaneously carried out, data verification, data reduction, data presentation using a data direct citation system used to strengthen/sharpen the analysis accompanied by data codes and identities (from the novel Rara Mendut/RM, Genduk Duku/GD, Lusi Lindri/LL) as stated in the table/data corpus. The meaning or interpretation of each data presented in chronological order/sequence as well as the group, linking it with an understanding of Michel Foucault's theory of archeology of knowledge and genealogy, then discussed by looking at the link between the text and the meaning of Michel Foucault's theory of knowledge archeology and genealogy in depth to get the findings. study. 


\section{RESULT}

\subsection{The System Of Thinking About Women By Huma Perspective Power}

The basis for the actions/treatment of women for the rulers of Mataram was the unwritten law of the kingdom that all women in the kingdom's territory belonged to the king/or nobility according to the king's instructions so that any kind of treatment for women was legal as illustrated by how the Crown Prince's mindset in the data the following GD novels.

Women work behind and obey. Like a kris. Only when he wants to use it, he is put in front and told to work. Then beautify yourself, well this is necessary and must. Furthermore...In Mataram all the women belong to Susuhunan, and I as the Crown Prince also have the right to own and require whom I will sleep with (Mangunwijaya, 2009, pp. 366-367)[8].

If the excerpt of the data is described as a reflection of the system of thought at that time that women/women in the eyes of the rulers were treated as decorations, even as inanimate objects without souls and their dignity was not touched by the thoughts of royal officials. Such treatment of women is based on a system of thought that has been firmly established among high-ranking officials/rulers of the Mataram kingdom.

\subsection{Systems of Thinking about Women and Power}

Systems of thinking about women and power in the Rara Mendut novel trilogy. A trilogy is told that women and power can be likened to two sides of a coin, cannot be separated, because both are related to one another. The kings and rulers of Mataram at that time thought that women were symbols of power or even supernatural powers. Therefore, it becomes a shocking incident if the woman who belongs to him, although still the future wife of Tumenggung Wiraguna, in the case of Tejarukmi, is kidnapped or taken away by the Crown Prince. The relationship between women and power is as recognized by the King of Mataram at that time as stated in the following GD data.

If he is good at seizing women, he will certainly be good at seizing kingdoms outside Mataram [8].

The excerpt of the data can be interpreted that women are synonymous with power and even the state/kingdom, therefore women's ownership can be identified with power ownership.

The system of thinking about women, which has always been associated with power, magic, and authority, was very colorful among the Mataram aristocracy at that time, so much so that it shocked the aristocracy when a girl, Rara Mendut, refused to be given a war prize as Tumenggung Wiraguna's wife. as in the following RM data.

Rara Mendut is not just a mendut beautiful body, but the embodiment of the soul of the north coast, the marines,... Rara Mendut is a rebellion

Based on Tumenggung Wiraguna's confession in the data excerpt, Rara Mendut is identical with the royal crown. Because being unable to conquer Rara Mendut is like a king who has lost his crown/honour.

It's really sad what happened to Rara Mendut and Pranacitra. Everywhere people tell the romance of the two people. But well, why do you dare to go against the will of the Great Commander of Mataram? It's called suicide. And why not? Isn't his name honorable, ketiban pulung? It is strange often young children. Girls should just obey. Mosok chooses his own husband. Obviously not worth it. [8]

The presentation of data from the GD novel explains that Rara Mendut is described as a female figure who is different from most women at that time. Most women at that time were always obedient, always obedient, not daring to argue, let alone choosing their own husband. Rara Mendut is described as a woman who has power over the will and chosen way of life even though it is contrary to what is common and even considered unworthy. Thus, it can be learned from this incident that good fortune must be fought for tenaciously based on the strength of a solid belief. Rara Mendut's strong determination with high fighting power can be used as a model for women in the present/millennial era in facing various challenges of the times.

\subsection{Systems of Thought about Women and Miracles}

The system of thinking about women and supernatural powers is closely related, especially among Javanese aristocrats because ownership of women is likened to having supernatural powers. Therefore, Javanese aristocrats tried to have many women which meant a lot of magic. On the other hand, just to be able to have what is called supernatural powers, a person takes various ways, even evil ones, forcing or even seizing him, like Ravana snatching Dewi Sinta in wayang. In such a government, women are considered as symbols of authority/magic, so if there are women who are desired to refuse twelve woes for officials/nobles who experience it because it means that their authority/magic is destroyed. Therefore, the katumenggungan Wiragunan was in an uproar when the daughter of a boyongan from Pati, Rara Mendut, refused to marry Tumenggung Wiraguna, the warlord of Mataram. The description of 
the system of thought can also be seen in the data from the following GD novel.

In Javanese aristocratic circles, the issue of romance is not only a matter of the pleasures of the flesh and the delicacy of the experience of beauty that strains the glands, but a matter of magic. Dewi Uma is the embodiment and guarantee of Sang Hyang Pramesti Guru Girinata's supernatural powers. For Prabu Rama, losing Sinta meant losing his supernatural powers, and seizing Sinta for Dasamuka was seizing the supernatural powers he did not have [8].

The data implies a picture that is so powerful the influence of women in relation as a symbol of magic. Ownership of a woman is the embodiment of ownership of magic, if someone loses the woman he has, it means he also loses his magic. On the other hand, the more women you have, the more powerful someone is. The greatest woman depicted during the reign of King Amangkurat I was the Queen of Malang. At that time it was described that even the most powerful king became very helpless when his beloved wife died to behave outside normal limits. This can be seen in the incident of King Amangkurat when his beloved wife died because of poisoning, since then his reign did not last long and continued to decline even after the collapse of Mataram and the king himself fled without followers.

In addition to the system of thinking about women which is very closely related to the power, sovereignty, magic, and authority of high-ranking royal officials, women on the other hand are also described as subordinated, harassed, considered dead objects, and not respected for their dignity, as seen in GD's data. following. "Since the budding girl she has known, every Mataram woman, that the nobility always feels entitled to the bodies of their subordinate women" [8].

The system of thought that underlies the discourse at that time and contrary to everything previously described about women, there was a binary opposition for women. Women on the one hand are described as noble, honorable, even powerful, but on the other hand they are also oppressed, persecuted, and abused and treated like inanimate objects.

Thus, the three systems of thinking about women reflected in the novel trilogy of Rara Mendut have been described and can inspire useful guidelines for life as an effort to build the nation's character so that they have a strong personality, are tenacious in their efforts, and have strong self-confidence.

\section{RECOMMENDATION}

From the discussion above, it can be concluded that first, the archeology of knowledge in Y.B.'s Rara Mendut novel trilogy. Mangunwijaya has a savoir in the form of philosophical ideas: about the nature of women related to virginity and generates the opinion that the nature of virginity is not merely physical but the most important thing is the soul; wife's loyalty is described as proof of the wife's devotion to her husband; the nature of brotherhood is not limited to blood relations only, but other people can also become brothers if they have the same taste and movement of the soul; Old age syndrome can infect anyone and from any circle, the essence of success does not lie in the worldly/outward nature, but instead triumphs in cultivating and controlling the personal self which is more important.

Second, genealogy in Y.B.'s Rara Mendut novel trilogy. Mangunwijaya includes the truth system and power mechanisms in the form of: the truth system in the name of state sovereignty, the truth system about taxes, the truth system about women as a symbol of glory, the truth system about abuse of power; the truth system about the political system of the king of Mataram, the truth system about the death penalty for failed officers, the truth system about women and the palace, the truth system about eliminating anyone who is considered an obstacle. All of these justification systems serve as the basis for justifying the arbitrary actions of the king/ruler. The system of truth and the mechanism of absolute power destroys the ruler himself and takes a heavy toll. And depending of the research on women's thinking systems in the trilogy of novels Rara Mendut by Y.B. Mangunwijaya can be recommended for: 1. Literary reader. Literary readers through reading the trilogy of novels, especially about the characters, can learn a lesson. The various systems of thinking about women that are revealed in the trilogy of novels can be used as material for reflection and can inspire/model in dealing with life's problems. 2. Teacher. The novel trilogy can be used as a medium for learning literature/teaching materials, especially at the high school and college level. 3. Parents. Parents with reading the trilogy can be used as models through the characters of the characters so that they motivate in educating children. 4. Policy makers. Various wise characters reflected in the novel trilogy can be used as models for policy makers because the characters revealed are a reflection of the character of a wise and wise leader.

\section{ACKNOWLEDGMENTS}

\section{THANKS TO STKIP PGRI JOMBANG}

\section{REFERENCES}

[1] Shihab, M. Quraish. 2005. Perempuan (... dari Cinta sampai Seks dari Nikah Mut'ahsampai Nikah Sunnah dari Bias Lama sampai Bias Baru...). Tangerang: Lentera Hati. 
[2] Bertens, K. 1985. Filsafat Barat Abad XX Jilid II Prancis. Jakarta: Gramedia.

[3] O'donnell, Kevin, 2013. Postmodernisme. Terjemahan Jan Riberu. Oxford: Lion Publising

[4] Foucault, Michel. 2008. La Volonte de Savoir, Histoire de la Sexualite. Terjemahan Rahayu S. Hidayat. Jakarta: Yayasan Obor Indonesia

[5] Ankersmit, F.R. 1987. Refleksi tentang Filsafat Sejarah. Jakarta: Gramedia

[6] Denzin, Norman K. dan Lincoln, Yvonna S. 2011. The Sage Handbook of Qualitative Research. California: Sage Publition
[7] Barker, Chris. 2013. Culture Studies. Yogyakarta: Kreasi Wacana

[8] Mangunwijaya, Y.B. 2009. Rara Mendut Sebuah Trilogi. Jakarta: Gramedia. [] Budianta, Melani. 2006. "Budaya, Sejarah, dan Pasar: New Historisism dalam Per-kembangan Kritik Sastra," dalam Susastra 3 (Jurnal Ilmu Sastra dan Budaya Universitas Indonesia). Volume 2 Nomor 3. 